University of Nebraska - Lincoln

DigitalCommons@University of Nebraska - Lincoln

To Improve the Academy

Professional and Organizational Development

Network in Higher Education

1997

Institutional Missions, Multiple Faculty Roles: Implications for

Faculty Development

Ann E. Austin

Joseph J. Brocato

Jonathan D. Rohrer

Follow this and additional works at: https://digitalcommons.unl.edu/podimproveacad

Part of the Higher Education Administration Commons

Austin, Ann E.; Brocato, Joseph J.; and Rohrer, Jonathan D., "Institutional Missions, Multiple Faculty Roles: Implications for Faculty Development" (1997). To Improve the Academy. 374.

https://digitalcommons.unl.edu/podimproveacad/374

This Article is brought to you for free and open access by the Professional and Organizational Development Network in Higher Education at DigitalCommons@University of Nebraska - Lincoln. It has been accepted for inclusion in To Improve the Academy by an authorized administrator of DigitalCommons@University of Nebraska - Lincoln. 
Austin, A. E., Brocato, J. J., \& Rohrer,J. D. (1997). Institutional missions, multiple faculty roles: Implications for faculty development. In D. DeZure (Ed.), To Improve the Academy, Vol. 16 (pp. 3-20). Stillwater, OK: New Fonms Press and the Professional and Organizational Development Network in Higher Education. Key Words: Faculty Role, Faculty Development, Instruction.

\title{
Institutional Missions, Multiple Faculty Roles: Implications for Faculty Development
}

\author{
Ann E. Austin
}

Joseph J. Brocato

\section{Jonathan D. Rohrer}

Michigan State University

The authors review the context in which the topic of faculty roles is gaining attention, draw on data from a qualitative study of how faculty construct their roles, and argue that faculty developers and other institutional leaders should consider expanding the scope of faculty development activities in ways that support faculty across the full breadth of their roles. The article concludes by suggesting that faculty developers ask questions about faculty roles in the institutional context and "map" faculty development opportunities to ensure that multiple roles are supported.

The topic of faculty roles has become a subject of concern to parents, employers, and legislators as well as university and college administrators and faculty members themselves (Edgerton, 1993a). In this 
article, we (1) review the context in which faculty roles are gaining attention, (2) draw on data from a qualitative study of how faculty construct their roles, focusing on their perceptions about these roles, and (3) argue that faculty development efforts should take an inclusive view to understand and develop faculty competence in their multiple roles. We conclude with implications for faculty developers and institutional leaders.

\section{The Context: Demands on Faculty to Fulfill Multiple Roles}

Demands for faculty to excel in a variety of roles are coming from both outside and within the academy. The public is concerned about how faculty members spend their time, whether they are giving enough attention to preparing undergraduates to enter and succeed in the workplace and to serve as responsible citizens, and whether they are directing their professional expertise to assist communities and other groups in addressing critical problems confronting society today. News articles frequently comment on how faculty spend their time, questioning whether faculty members should allocate their time as they do. The public is demanding accountability and demonstrable student learning outcomes from colleges and universities. Public expectations call for faculty members to succeed in several roles; that is, members of the professoriate, at least collectively, should be excellent teachers, knowledgeable and compassionate advisors, productive researchers, and able translators of research findings to help redress societal problems (Fairweather, 1996; Winkler, 1992).

Within higher education itself, there is considerable discussion about faculty members' multiple roles and responsibilities, including teaching, research, public service, and institutional citizenship (Blackburn \& Lawrence, 1995; Rice, 1996). The particular configuration of missions varies across institutional types, thereby requiring somewhat differing roles from faculty (Austin, 1990, 1992a; Clark, 1985; 1987; Ruscio, 1987). Liberal arts colleges and community colleges historically have emphasized undergraduate education and thus call on faculty to be excellent teachers. At many liberal arts colleges, however, some faculty also feel a personal commitment to contribute to 
the scholarship in their discipline, and in some cases, the college itself urges and rewards research and publication. Within comprehensive institutions, faculty are pressed to fulfill heavy teaching responsibilities while they also develop significant research agendas and meet responsibilities as institutional citizens. At the research universities, and particularly those with both research and land-grant traditions, multiple missions must be met. These include knowledge discovery and creation (research), knowledge dissemination (teaching), and knowledge application (outreach or public service to external constituencies). The broader definitions of scholarship offered by Boyer and Rice (Boyer, 1990) have been adopted by many institutions as useful ways to frame the varieties of kind of work that faculty members are called upon to perform.

Faculty members themselves are aware that they must fulfill a myriad of different tasks and that, at an increasing number of institutions, the evaluation and reward structures are predicated on excellence in at least several kinds of responsibilities. The literature on new and early career faculty reflects their uncertainty in how they should interpret multiple messages about expectations and balancing their diverse roles (see, for example, Austin, 1992b; Eimers, 1990; Menges, 1996; Myers \& Mager, 1980; Olsen, 1990; Sorcinelli, 1989, 1992; Sorcinelli \& Near, 1989; Tierney \& Bensimon, 1996; Whitt, 1991).

The interest in faculty roles is especially apparent in several funded and nationally recognized projects. The American Association for Higher Education has held a National Forum on Faculty Roles and Rewards for five years, with attendance increasing annually to a number exceeding 1,000 in early 1997 . At this conference, institutional leaders and faculty exchange information, ideas, and strategies for conceptualizing faculty roles, supporting faculty as they take on new roles, evaluating faculty work in various arenas, and facilitating organizational change that recognizes and supports the varieties of faculty work (Edgerton, 1993b). With support from The Pew Charitable Trusts, the Council for the Advancement of Private Higher Education (CAPHE) and the Council of Independent Colleges (CIC) are in the midst of a two-year project entitled "Faculty Roles, Faculty Rewards, and Institutional Priorities". This project supports twentytwo colleges that are engaged in projects and exchange of ideas 
concerning changes and challenges in faculty roles within private, liberal arts-focused institutions. Another Pew-supported project led by researchers at Michigan State University is entitled "Realigning Institutional Missions and Faculty Work." This project is enabling six large universities to exchange ideas as they each are involved in significant institutional change processes pertaining to closer alignments between their multiple institutional missions and faculty work.

These three efforts reflect the awareness of educational leaders that the roles of faculty are an important focus for attention. Key issues concern what these multiple roles are, who should perform what roles, how these roles should be evaluated and rewarded, and how faculty work roles relate to broader institutional missions. For faculty members themselves, the questions and issues may be more modest: What am I expected to do? How do my personal affinities for particular roles relate to expectations from my colleagues, department chairperson, dean, and others? How can I balance the several key roles of teacher, researcher, institutional citizen, and outreach or service contributor? What do some of these roles actually mean for my own life and work?

\section{Reflections and Themes from a Study of Faculty Roles}

Over the past two years, we have conducted a modest qualitative study entitled, "Constructing the Role of College Teacher: College Teachers Reflecting on College Teaching." This study involved twenty faculty members in the humanities and social sciences evenly divided between those in a community college and those in a research university. Half the participants were in their first three years of teaching and half were faculty with more than fifteen years of experience. The study was designed to explore faculty perceptions in three areas: philosophy and beliefs concerning teaching and learning processes, the developmental process of constructing the teaching role over time, and the teaching role in relation to other roles. Each faculty member participated in three in-depth interviews. Questions we asked about faculty roles included: What are the array of roles that you fulfill as a university professor? How do your roles complement each other? Do the roles you must fulfill interfere with each other? What do you 
see as the other roles, in addition to being a faculty member, that you fulfill in your life? How do other roles and responsibilities in your life affect you as a teacher?

Data analysis involved three teams of at least two researchers probing each interview for themes, identifying emerging coding categories, assigning data to emerging categories, and developing new categories to accommodate the array of data. Throughout the analysis, inter-rater reliability was checked repeatedly.

\section{Themes regarding Faculty Perceptions of Their Roles}

Our purpose in this article is not to provide a comprehensive research report from this qualitative study. Rather, we highlight those themes that concern faculty perceptions of their multiple roles and their teaching role in relation to their other roles, comparing responses from different institutional types. Consideration of these faculty perspectives, as well as of the societal context within which universities and colleges are situated, leads us to recommend that faculty developers concern themselves with the full array of roles that faculty must fulfill.

Faculty emphasis on traditional roles. Ninety percent of participating faculty members from both the research/land-grant university and the community college were aware of two primary roles: teaching and research. At the community college, only two faculty talked of research responsibilities, although seven indicated that they pursue research activities to satisfy their own interests and commitments. When asked to comment on their responsibilities, eighteen of the twenty faculty did not mention the full array of responsibilities' that they fulfill. That is, they commented infrequently on their advising duties, outreach and service expectations, and institutional citizenship roles, such as committee work. However, one community college faculty member did comment that "committee work is enough to make me want to retire from teaching."

The faculty members at the research/land-grant university are working within an institutional culture in which senior leaders discuss publicly the institution's multiple missions. Evaluation and reward policies relate directly to faculty work across the missions of teaching, 
research, and outreach. The general lack of comment on roles beyond teaching and research raises questions about: (1) whether the faculty are indeed fully aware of the institutional emphasis on multiple institutional missions and multiple faculty roles and (2) whether faculty development efforts might be usefully directed to helping faculty better understand the full array of role expectations that the institution expects them to meet (e.g., involvement in outreach/public service).

Mixed messages from others about faculty roles. Consistent with other research findings (Austin, 1992b; Boice, 1992; Finkelstein and LaCelle-Peterson, 1992; Stanley and Chism, 1991; van der Bogert, 1991; Tierney and Bensimon, 1996), participants reported that they often hear conflicting messages about what roles they should fulfill. Institutional leaders may speak generally about the institutional missions, including public service and outreach; deans may assert that teaching is a highly valued activity; and, department chairpersons as well as faculty colleagues may give signals that research and publication records are the primary basis of professional success. For early career faculty members, the dilemma of perceiving sometimes contradictory messages is especially confusing. For example, one university faculty member in social sciences commented:

I think the department expects me to teach, but when it comes to tenure, it is pretty clear that research is primary. I' $m$ sure teaching is important at a certain level. I'm sure that it is important that I have an acceptable level of teaching, but I've gotten the feeling in messages from other people that I shouldn't be devoting huge amounts of time to teaching. It is more important to do research.

If a college or university expects its faculty members to fulfill a variety of responsibilities with excellence, including public service, advising, and committee assignments as well as teaching and research, it may be fruitful to design faculty development efforts that help faculty think through these various roles, assess conflicting messages about role expectations, and evaluate their own role choices within a context of diverse messages. In comparison to the university faculty, the faculty at the community college receive a fairly clear signal that teaching is their primary role; nonetheless, three faculty still indicated 
that they receive few explicit messages about how well they are fulfilling this role.

Role stress. Seventy percent of the participants in the study at both the university and the community college commented on the press of the workload within limited time and the ongoing struggle they face to find ways to balance multiple faculty roles. One seasoned community college faculty member in social sciences explained how workload and time pressures constrain his ability to include more diversity in his faculty roles:

Teaching is my major function...everything else becomes second priority to me, especially because I want to do teaching well....I would like to do other things besides teaching, such as research...but with teaching 18-19 hours per semester, there just isn't the time!

The ability to prioritize in the face of multiple demands does not come easily to all faculty, although a few seasoned faculty members indicated that they have managed to develop this ability. One community college faculty member in social sciences explained:

In the beginning, I didn't prioritize and balance well and I went stark raving crazy...I think I didn't start slowing down until maybe three years ago (year seven) when I really began to take a look at the word 'no' in my vocabulary.

In addition to the strategy of declining various responsibilities, four participants reported that, over time, they discovered ways to integrate the work they did in different aspects of their roles. A community college faculty member explained, "I decided...I am doing all this [different stuff], ...I might as well try to use it in some way."

At both the university and the community college, successful experienced faculty had learned ways to balance demands, to prioritize various role expectations, and to integrate and build on different kinds of work responsibilities, so that efforts were more complementary and less isolated from other efforts. Early career faculty were still learning these skills (a finding consistent with conclusions from other research). While some colleges and universities already provide guidance, support, and information for new faculty to help them consider principles of balance, prioritization, and integration of work efforts, 
perhaps more attention to strategies for dealing with multiple roles would be appropriate in faculty development efforts.

Relationship between faculty and non-faculty roles. Participants in the study were asked what other roles they must fulfill (e.g., parent, spouse, civic leader) and how these other roles relate to their faculty responsibilities. While all the participants reported responsibilities outside the university or college, such as family duties, they tended to demonstrate a lack of reflection on the relationship between non-faculty and faculty roles. As one community college faculty in humanities commented, "I know that other non-faculty roles impact my teaching, but I have never pondered it and started to think about it." As we considered this lack of reflection about the relationship between faculty and non-faculty roles, it occurred to us that some faculty members might benefit from opportunities to focus on the range of roles they are expected to fulfill in their lives and on the strategies that might assist them to address each role as effectively as possible. Though our data did not probe special issues in the non-work domain for particular groups of faculty, it seems likely that early career faculty who have young families might find faculty development support related to balancing work and non-work roles to be helpful .

Summary of themes. As expected, responses from the faculty participants in the two different types of institutions did indicate the different emphases of each of these institutional types. Role expectations are more diverse in research/land-grant institutions than in community colleges. Teaching is the primary role in the community college, while research and teaching are both key faculty roles in the university. Despite these institutional differences, several common themes emerged.

First, faculty typically do not appear to be thinking through and articulating ideas about the full array of roles that they must fulfillteacher, researcher (at least in the university), public service or outreach contributor, advisor, institutional citizen, to name several key roles. Second, the workplace has high demands, and the conflicting messages about fulfilling different roles are confusing. These two observations suggest that faculty development initiatives could be conceptualized and organized specifically to help faculty members 
conduct their work in environments where multiple faculty roles and responsibilities are the norm.

\section{Considerations and Implications for Faculty Development}

On many campuses, faculty development efforts focus primarily on assisting faculty to fulfill their teaching roles and responsibilities (Gaff \& Simpson, 1994); this is clearly an appropriate concern. However, in this article, we are suggesting that faculty developers and other institutional leaders should consider expanding the scope of faculty development activities in ways that support faculty across the full breadth of their roles.

Certainly, the specific roles and responsibilities that might be supported through faculty development efforts should vary by institutional type. As already discussed, teaching is the primary responsibility for faculty in liberal arts and community colleges, but faculty also have significant responsibilities as institutional leaders, committee members, and advisors. In the comprehensive institutions and research-oriented and land-grant universities, teaching indeed is a primary role and responsibility, but faculty also are often expected to engage in public service and outreach and to assume advising and institutional citizenship roles. Faculty have usually been prepared for their research roles through their graduate school preparation. However, faculty may not have learned to manage this role in the context of multiple additional responsibilities or to find connections among their various roles.

We are suggesting here that many universities and colleges may find it useful to expand their conceptions of faculty development in order to link individual development more fully with institutional needs and expectations. As universities and colleges assess the particular societal expectations that they choose to address-that is, as they clarify their missions - and as they ask their faculty to excel in a variety of kinds of work, examination of whether and how faculty members are supported in these multiple roles will assist both the individual to succeed and the institution to thrive. In this way, individual needs and interests and institutional commitments are joined. Now 
we offer two specific suggestions for how institutional leaders and faculty developers might conceptualize and approach faculty development in ways that recognize and support the multiple roles that faculty play.

\section{Ask Questions about Faculty Roles in the Institutional} Context

One way for faculty developers and other senior institutional leaders to begin is to ask questions about the institution and its culture and missions, about expectations facing faculty, and about the concerns faculty have about meeting these expectations. Institutional leaders, deans and department chairpersons, and faculty members themselves could be invited into the conversation. Several questions might serve to focus these conversations:

a. What are the missions of the institution? Have these missions changed in recent years?

b. What roles and responsibilities are faculty expected to fulfill? How do these roles and responsibilities relate to the missions of the institution? Which roles are primary and which are secondary?

c. From the point of view of faculty members themselves, which roles would benefit from faculty development support? From the point of view of deans and chairpersons, which faculty roles should be more fully supported? The response may vary across the units of an institution. For example, extensive undergraduate advising may be a new responsibility for faculty in one department or college but may have been handled routinely for years by faculty in another.

d. What are the specific challenges or professional development needs of faculty as they address particular roles and responsibilities? Which of these challenges or needs might be fruitfully addressed through faculty development efforts?

e. What are the current scope and focus of the institution's faculty development efforts? While the professional development of faculty in the teaching role may be addressed through a center or office specifically charged to address teaching 
issues, we suggest that a response to this question might involve a review of the variety of offices, centers, and personnel that may assist faculty in their various roles. For example, a Grants and Contracts Office may be offering regular seminars available to faculty who wish to strengthen their grantsmanship skills.

f. Are there roles and responsibilities faculty are expected to fulfill which are not supported through professional development opportunities?

Faculty, deans and chairpersons, and faculty developers may answer these kinds of questions in different ways. Focus groups can provide extensive information about the institution's missions, the ways in which faculty and others view their roles and responsibilities, the needs and challenges confronted by faculty as they go about their work, the ways in which professional development efforts already are assisting both the institution and the individual faculty member, and the kinds of faculty development efforts that would provide additional needed clarification and resources for faculty to perform all their roles.

\section{Map Faculty Development across Faculty Roles}

Faculty developers who see their role as supporting faculty across the range of their multiple roles will find it fruitful to reflect on responses to questions about the institution's missions and the implications for faculty roles. Additionally, a next useful step is to audit or "map" the institution's existing faculty development efforts to identify the faculty roles that are being supported.

Not all efforts to assist faculty are located in one office. A variety of services may be situated in a faculty development office, a teaching excellence center, the provost's office, the grants and contracts office, the service learning center, the writing center, or within the deans' offices.

One way to analyze or audit the available faculty development resources is to identify the particular missions of the institution and their implications for faculty, and then to list the particular resources that support each mission and the unit providing each resource. Under the "teaching mission," for example, many institutions can list semi- 
nars and workshops, consultation services, mid-semester course evaluations, curriculum development grants, teaching excellence awards, and teaching fellows programs for junior or senior faculty. Under the "research mission," institutions might identify computer resources to facilitate searches for grant funding, consultants to assist faculty with research proposal writing, mentor programs to support early career faculty as they establish research agendas, seminars in which faculty members discuss research activities and projects, and seed grant programs.

Activities under the heading of the "public service/outreach mission" are likely to be fewer at most institutions. At Michigan State University, one innovative effort that helps faculty explore possibilities for their public service/outreach role involves bus trips that take groups of faculty to visit sites where other faculty are applying their expertise to community needs. Trips might include visits to rural health clinics, youth organizations, and businesses. These trips may be scheduled to cover two or three days, providing considerable opportunity for faculty participants to interact, discover mutual interests, and increase their connections with colleagues from across the institution. In this way, this strategy helps achieve several faculty development goals simultaneously: faculty members learn more about the outreach and public service mission of the institution, they may find possible research collaborators for interdisciplinary problem solving, and they expand their collegial connections. Other resources that might be included under the "outreach mission" are (1) seed grant programs to support faculty as they develop links with community groups and (2) the availability of "brokers" on the university professional staff who have particular expertise in helping faculty members and representatives of community agencies explore the possibilities of joining interests.

In addition to specifying the institutional missions and the faculty roles that are related to those missions, the conceptual approach we are suggesting includes consideration of the career stages of faculty. Faculty developers have long recognized the importance of faculty needs at various career stages (see, for example, Austin, 1992b; Baldwin and Blackburn, 1981; Finkelstein and LaCelle-Peterson, 1993). A carefully conceptualized faculty development program 
might offer new faculty some basic support and information about institutional missions and related role expectations. Faculty members preparing for tenure consideration might be offered special sessions concerning ways to document their roles and accomplishments in the different mission areas. Accomplished researchers in mid or late career might find new possibilities for professional contribution in the outreach-oriented bus trips described above.

This kind of conceptualization could be represented by a grid with the institutional missions and related faculty roles listed across the horizontal axis and the career stages along the vertical axis. The horizontal axis might also include a section for listing resources that help faculty with all three mission areas and with balancing work roles with personal roles. For example, seminars on balancing faculty and non-faculty responsibilities may assist early career faculty especially, and faculty across the ranks may benefit from seminars on time management or stress relief. An example of a grid for mapping faculty development resources is provided in Figure 1. This grid offers a framework through which faculty developers can identify the array of resources which are available across the various units within the institution and those mission/role areas and career stage areas in which additional resources would be helpful.

While we are arguing for an approach to faculty development that is more expansive than is customary at many institutions, several points should be emphasized. First, our suggestion that faculty development be conceptualized more broadly does not imply that teaching centers are inappropriate or that faculty development specialists who focus specifically on teaching improvement are too narrow in their expertise. Rather, we are suggesting that, at the institutional level, faculty development should be conceptualized as a set of resources that support faculty in the full array of multiple roles that they are expected to fulfill. By focusing on faculty development at the institutional level, we are emphasizing that faculty development can productively include a range of units and resources on a campus. Those who focus on the teaching mission (such as teaching excellence centers) are indeed central to an institution's faculty development efforts; however, individuals who work in areas such as the office of grants 
and contracts, the library, and the writing center, to name a few, might also be included as part of the institution's faculty development efforts.

Second, institutions vary in their missions and their range of faculty development resources. Nevertheless, a conceptual approach that emphasizes the diverse roles that faculty are expected to play within the specific institutional context can help ensure that faculty can find an appropriate array of faculty development opportunities.

Finally, we believe that a conceptual approach to faculty development that incorporates attention to the particular missions of the institution, the faculty roles and responsibilities associated with those missions, and the career stage challenges faced by individual faculty will help link institutional and individual needs. If a university or college ensures that faculty members have the appropriate support to meet each of the multiple roles they are expected to fulfill, the institution can meet its missions more completely and faculty mem-

\begin{tabular}{|c|c|c|c|c|}
\hline \multicolumn{5}{|c|}{$\begin{array}{l}\text { Figure } 1 \\
\text { Framework for Mapping Faculty Development Resources }\end{array}$} \\
\hline \multicolumn{5}{|c|}{ Resources to Support Faculty Roles } \\
\hline \multicolumn{5}{|c|}{ Institutional Missions } \\
\hline $\begin{array}{l}\text { Resources for } \\
\text { Faculty Career } \\
\text { Stages: }\end{array}$ & $\begin{array}{l}\text { Column A: } \\
\text { Teaching }\end{array}$ & $\begin{array}{l}\text { Column B: } \\
\text { Research }\end{array}$ & $\begin{array}{c}\text { Column C: } \\
\text { Public } \\
\text { Service/Outreach }\end{array}$ & $\begin{array}{l}\text { Column D: } \\
\text { Integrated Roles }\end{array}$ \\
\hline \multicolumn{5}{|l|}{ Row 1: Early Career } \\
\hline \multicolumn{5}{|l|}{ Row 2: Mid-Career } \\
\hline \multicolumn{5}{|l|}{ Row 3: Late Career } \\
\hline \multicolumn{5}{|l|}{$\begin{array}{l}\text { Row 4: Resourcos } \\
\text { for all Career Stages }\end{array}$} \\
\hline \multicolumn{5}{|c|}{$\begin{array}{l}\text { Instructions: } \\
\text { Within each cell, list available resources and the unit providing each resource. In column } \\
\text { A, list resources specifically pertaining to the Teaching role; in Column B, resources } \\
\text { pertaining to the Research role; in Column C, resources pertaining to the Public } \\
\text { Servico/Outreach role; in Column D, resources that assist faculty with all three roles and } \\
\text { with balancing work and personal roles. } \\
\text { In Row 1, list resources specifically for early career faculty; in Row 2, resources for mid- } \\
\text { career faculty, in Row 3, resources for late career faculty; in Row 4, resources for faculty at } \\
\text { all career stages. }\end{array}$} \\
\hline
\end{tabular}


bers are more likely to achieve personal satisfaction and success. In this way, faculty development can be organized to address both the professional development of individuals and the organizational development of the institution.

\section{References}

Austin, A. E. (1990). Faculty values, faculty cultures. In W. G. Tierney (Ed.), Assessing academic climates and cultures (New Directions for Institutional Research No. 68) (pp. 61-74). San Francisco: Jossey-Bass.

Austin, A. E. (1992a). Faculty cultures. In A. I. Morey (Ed.), The encyclopedia of higher education, Vol. 4. (pp.1614-1622). New York: Pergammon Press.

Austin, A. E. (1992b). Supporting junior faculty through a teaching fellows program. In M. D. Sorcinelli, \& A. E. Austin (Eds.), Developing new and junior faculty (New Directions for Teaching and Learning No. 50) (pp. 73-86). San Francisco: JosseyBass.

Baldwin, R. G., \& Blackburn, R. T. (1981). The academic career as a developmental process: Implications for higher education. Journal of Higher Education, 52, 598614.

Blackburn, R. T., \& Lawrence, J. H. (1995). Faculty at work: motivation, expectation, satisfaction. Baltimore: The Johns Hopkins University Press.

Boice, R. (1992). The new faculty member. San Francisco: Jossey-Bass.

Boyer, E. L. (1990). Scholarship reconsidered: Priorities of the professoriate. Princeton, NJ: Camegie Foundation for the Advancement of Teaching.

Clark, B. R. (1985). Listening to the Professoriate, Change, 17, 36-43.

Clark, B. R. (1987). The academic life: Small worlds, different worlds. Princeton, NJ: Carnegie Foundation for the Advancement of Teaching.

Edgerton, R. (1993a). The re-examination of faculty priorities. Change, 25, 10-25.

Edgerton, R. (1993b). Thoughts from the first forum on faculty roles and rewards. Change, 25, 18-19. ।

Eimers, M. (1992). Background and experiences of new faculty. Instructional Developments, 3, 12-15.

Fairweather, J. S. (1996). Faculty work and public trust: Restoring the value of teaching and public service in American academic life. Boston: Allyn and Bacon.

Finkelstein, M. J., \& LaCelle-Peterson, M. W. (1992). New and junior faculty: A review of the literature. In M. D. Sorcinelli \& A. E. Austin (Eds.), Developing new and junior faculty (New Directions for Teaching and Learning No. 50) (pp. 5-14). San Francisco: Jossey-Bass.

Finkelstein, M. J., \& LaCelle-Peterson, M. W. (Eds.). (1993). Developing senior faculty as teachers (New Directions for Teaching and Learning, No. 55). San Francisco: Jossey-Bass. 
Gaff, J. G., \& Simpson, R. D. (1994). Faculty development in the United States. Innovative Higher Education, 18(3), 167-76.

Lipetz, M., et al. (1986). Rethinking faculty development. Medical Teacher, 8, 137-44.

Menges, R. J. (1990). Experiences of newly hired faculty. In L. Richlin (Ed.), To Improve the Academy, Vol. 15 (pp. 169-182). Stillwater, OK: New Forums Press and the Professional and Organizational Development Network in Higher Education.

Myers, B., \& Mager, O. M. (1980). The emerging professsoriate: A study of how new professors spend their time. ERIC Clearinghouse for Higher Education. (ERIC Document Reproduction Service No. ED 220 429)

Olsen, D. (1990). Work satisfaction and stress in the first and third years of academic appointment. Paper presented at the annual meeting of the Association for the Study of Higher Education, Portland, OR.

Rice, R. E. (1996). Making a place for the new American scholar (New Pathways Working Paper Series). Washington, DC: American Association for Higher Education.

Ruscio, K.P. (1987). Many sectors, many professions. In B. R. Clark (Ed.), The academic profession: National, disciplinary, and institutional settings. (pp.331-368). Berkeley, CA: University of California Press.

Sorcinelli, M. D. (1988). Satisfactions and concerns of new university teachers. In J. G. Kurfiss (Ed.), To Improve the Academy, Vol. 7, (pp. 121-31). Stillwater, OK: New Forums Press and the Professional and Organizational Development Network in Higher Education.

Sorcinelli, M. D. (1992). New and junior faculty stress: Research and responses. In M. D. Sorcinelli \& A. E. Austin (Eds.), Developing new and junior faculty (New Directions for Institutional Research No. 50) (pp. 27-37). San Francisco: Jossey-Bass.

Sorcinelli, M. D., \& Near, J. (1989). Relations between work and life away from work among university faculty. Journal of Higher Education, 60, 59-81.

Stanley, C. A., \& Chism, N. V. (1991). Selected characteristics of new faculty: Implications for faculty development. In K .J. Zahorski, et al. (Eds.), To Improve the Academy, Vol. 10 (pp. 55-61). Stillwater, OK: New Forums Press and the Professional and Organizational Development Network in Higher Education.

Tierney, W. G., \& Bensimon, E. M. (1996). Promotion and tenure: Community and socialization in academe. Albany, NY: State University of New York Press.

van der Bogert, V. (1991). Starting out: Experiences of new faculty at a teaching university. In K. J. Zahorski, et al. (Eds.), To Improve the Academy, Vol. 10 (pp. 63-81). Stillwater, OK: New Forums Press and the Professional and Organizational Development Network in Higher Education.

Whitt, E. J. (1991). Hit the ground running: Experiences of new faculty in a school of education. The Review of Higher Education, 14, 177-197.

Winkler, A. M. (1992). The faculty workload question. Change, 24, 36-41. 


\section{Contact:}

Ann E. Austin

Associate Professor

Department of Educational Administration

417 Erickson Hall

East Lansing, MI 48824

(517) 355-6757 (phone)

(517) 353-6393 (fax)

aaustin@msu.edu (e-mail)

\section{Joseph J. Brocato}

Faculty Development Specialist

COGMET-SCS Faculty Development

325 West Fee Hall

East Lansing, MI 48824

(517) 355-8301 (phone)

(517) 432-4014 (fax)

brocato@com.msu.edu (e-mail)

Ann E. Austin is an Associate Professor in the Graduate Program in Higher, Adult, and Lifelong Education at Michigan State University. Her research interests concern faculty careers, faculty development, organizational change in higher education, and the improvement of teaching and learning. Currently she is a co-director of a longitudinal study concerning the development of graduate students as teaching scholars as well as a project on realigning institutional missions and faculty work. She contributes regularly to the faculty development program at Michigan State University.

Joseph J. Brocato is a Faculty Development Specialist in the College of Osteopathic Medicine at Michigan State University. His research interests, both inside medical and higher education, include faculty work and productivity, faculty development, and instructional and educational technology. He is currently completing a Ph.D. in Higher Adult and Lifelong Education within the Department of Educational Administration at Michigan State University.

Jonathan D. Rohrer is a Curriculum Development Specialist in the College of Osteopathic Medicine at Michigan State University. His current research interests include faculty work and faculty development as well as adult leaming communities and mentoring dyads. He is currently completing a Ph.D. in Higher Adult Lifelong Education within the Department of Educational Administration at Michigan State University.

The senior author appreciates conversations with the following people at Michigan State University who have contributed to her thinking about ways in which faculty development efforts can support faculty work across the full range of institutional missions: Dr. Karen Klomparens, 
Assistant Dean of the Graduate School; Dr. Kathryn Moore, Director, Center for the Study of Advanced Learning Systems; Dr. Nancy Pogel, Secretary of the Board of Trustees and Assistant to the President; Dr. Donald Straney, Assistant to the Provost for Faculty Development at Michigan State University; and Dr. James Votruba, until recently, Vice Provost for Outreach at Michigan State and now President, Northern Kentucky University. 